\title{
COVID-19 and Adult Education - a Path to Transformation of Regions in Latvia
}

\section{Inga Jekabsone}

Magnetic Professional, Ltd, 78-1 Gustava Zemgala Avenue, Riga, LV-1039, Riga, Latvia, jekabsone47@gmail.com

Annotation. This research examines the consequences of COVID-19 on the adult education sector in Latvia in the context of regional restructuring. A survey of adult education institutions of Latvia $(\mathrm{N}=60)$ was used as the main research method. Main findings of the research: in the pandemic context, the main challenges in the adult sector are related to the lack of digital skills, technological issues, and transformation of the content of the subject to distance learning.

Keywords: COVID-19, adult education, digitalisation, regions, Latvia, transformation.

\section{Introduction}

The pandemic has changed the world's digital transformation. At the EU level, European Commission has stated that digital technology is a key component of collective effort to tackle the virus and support new ways of living and working reality during this exceptional time (European Commission, 2021). Digital will also play an important part in the economic recovery, as the European Council and the Commission have agreed to structure recovery assistance with the dual transition to a climate-neutral and resilient digital transformation. In this paradigm, digital skills, company digitisation, and public administration digitisation are critical for a strong recovery (European Commission, 2020a).

In addition, the Digital Education Action Plan 2021-2027 further supports the development of online learning at different levels of education across Europe (European Commission, 2020b).

Several studies have explored the benefits of online adult learning and training, particularly in the context of social inclusion (Diep et al., 2017; de Greef et al., 2015; Cocquyt et al., 2017) improvement of various skills (such as self-regulating) and competencies (Lee 
et al., 2019). There is evidence that online learning can improve work-life balance for the majority of adult students, particularly when contrasted to traditional fixed time and place classroom instruction (Berry \& Hughes, 2020). At the same time, the research on online learning in adult education shows that one of the main challenges is relatively high dropout rates. In more detail, the success factors of online adult learning that address the challenge regarding the high dropout rate are as follows: credibility, transparency, flexibility, accessibility, interactivity, personalisation, and productivity (Blieck et al., 2019a). Adult students perceive that the quality dimensions of learning activities and student support (related to interactivity) deserve priority in improving participation in online learning in adult education (Blieck et al., 2019b).

Because adult students have various life, career, and educational experiences, they have diverse competencies (Barnard-Brak et al., 2020), making a one-size-fits-all strategy unsuitable for helping adult students. Adult students' learning requires the optimization and personalization of their support (Vanslambrouck et al., 2019).

In the context of COVID-19 related restrictions, adults have been learning and training in unprecedented ways leading to the improvement of technologies and methods for the distance learning process. In a relatively short period, educational institutions providing adult learners with programmes had to shift to the distance learning process to maintain their competitiveness. Some institutions even had found an opportunity to expand their activities as distance learning may attract an additional target audience.

In the case of Latvia, educational institutions, including adult education institutions, shifted to the distance learning process in March 2020. The government had initiated different support mechanisms like support from European Structural funds to online educational programmes, technological solutions, training to teachers and administration of adult education institutions, etc. Furthermore, the Educational Law of Latvia (Latvijas Vestnesis, 1998) states that face-to-face courses may incorporate a component of distant learning, allowing educational institutions to organise a hybrid learning process even after the COVID-19-related restrictions are lifted.

Analysing the case of Latvia regarding the recent digital progress that is crucial in the context of the development of distance adult learning and training, Latvia ranks 18th out of the 28 EU Member States according to Digital Economy and Society Index (DESI) in 2020. Latvia's ranking fell three places compared to DESI 2019. Latvia scores well below average in digital skills. More than half of the population still lack basic digital skills and ICT specialists represent $1.7 \%$ of total employment (EU average: $3.9 \%$ ) (European Commission, 2020a). Thereby, it may be concluded that one of the main challenges in the development of the distance adult education sector may be a lack of digital skills.

It should also be stressed that online learning and training have the potential to contribute to the polycentric development that is indicated as one of the long-term priorities of Latvia (Cross-Sectoral Coordination Centre of Latvia, 2010). Riga is a centre of economy, formal and non-formal education; however, the city may not be reachable for 
all potential learners from the regions. In turn, well-developed distance adult learning may create all necessary conditions when adult learners may apply for the programme of interest regardless of location.

The goal of this research is to examine the consequences of COVID-19 on the adult education sector in Latvia in the context of regional restructuring.

Tasks are formulated as follows:

1. to analyse the results of the survey of Latvian educational institutions that organise adult learning and training processes on the consequences of COVID-19 to their operational work;

2. to define the main challenges of Latvian educational institutions that organise adult learning and training processes in the context of COVID-19.

To achieve the purpose, the following research methods have been used: scientific literature studies, a survey of adult education institutions of Latvia $(\mathrm{N}=60)$. Survey results were analysed using indicators of descriptive statistics (indicators of central tendency or location - arithmetic mean, mode, median), indicators of variability (indicators of dispersion - range, standard deviation, and standard error of the mean); analysis of variance - ANOVA was used as well.

The paper is original and topical as it analyses the consequences of COVID-19 on the adult education sector in Latvia. The value of the paper is highlighted by surveying a representative number of adult education institutions in Latvia, including the regional aspect as well. It is planned that the results of the survey will be used in policy planning in the adult education sector in Latvia as well as in the development of recommendations and methodological materials for adult education institutions in Latvia promoting distance and hybrid adult educational process.

\section{Materials and methods}

The authors surveyed in May and June 2021 via Webropolsurveys. The target audience of the survey was educational institutions in Latvia that organise adult learning and training.

The adult education sector was analysed in the previous author's paper (Jekabsone \& Gudele, 2021). In Latvia, adult education programmes may be organised by the educational institutions and by the legal and natural persons which are not registered in the Register of Educational Institutions (after receipt of a license from a local government); however, these organisations are not significant players in adult education market. Thereby, it was decided to focus on organisations that are registered in the Register of Educational Institutions (app. 100 institutions) (Ministry of Education and Science of Republic of Latvia, 2021). 
The questionnaire was developed in collaboration with the Ministry of Education and Science of the Republic of Latvia, the State Education Development Agency, Latvian Adult Education Association, and other social partners. The invitations to participate in the survey were sent by email to all registered educational institutions. In addition, the invitation was published on the websites and social media accounts of the abovementioned cooperation partners. In total, 60 educational institutions participated in the survey; however, 43 educational institutions completed the questionnaire in full. It also should be mentioned that mostly, these educational institutions are active and participate in various projects that support adult education and training in Latvia.

Also, analysing the geographical distribution of surveyed educational institutions, it was concluded that it corresponds to the actual geographical distribution of educational institutions in Latvia. The same refers to the offered form of the learning process (faceto-face; distance; both).

Thereby, it may be concluded that the sample is representative and the results of the survey may be used in interpretation describing the whole Latvian adult education sector.

\section{Results}

Within the survey, educational institutions were asked to choose the relevant strategy regarding their activities due to COVID-19. As it is revealed in Figure 1,30\% of educational institutions were able to adapt their activities to the distance learning process without significantly changing the way of operations.

\section{Figure 1}

Strategies of Educational Institutions in the Context of COVID-19

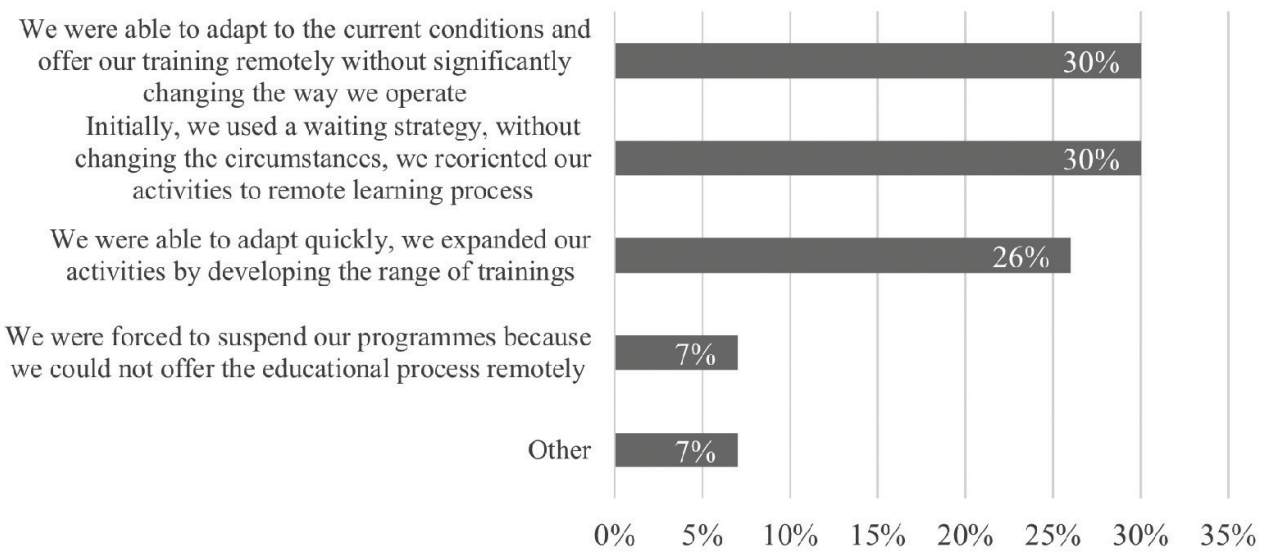

Note. Figure developed by the author based on the results of the survey $(N=43$; research period: May-June 2021) 
A similar share of educational institutions used the so-called waiting strategy and reoriented their activities to the distance learning process. In turn, $26 \%$ of educational institutions even expanded their activities by developing a range of programmes and training. Only $7 \%$ of surveyed educational institutions admitted that they were forced to suspend their activities as they could not offer distance education programmes.

At the same time, $89 \%$ of all surveyed educational institutions admitted that they will continue to offer both face-to-face and distance adult education programmes also in the post-COVID-19 period (see Figure 2). These results support the findings of other scholars on the advantages of online education (e.g., see Lee et al., 2019).

\section{Figure 2}

Future Strategies of Educational Institutions Regarding the Form of the Learning Process

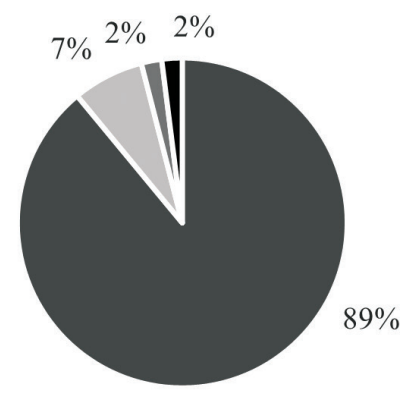

- We plan to offer both faceto-face and distance learning

- It is not yet clear about the future plans

- We plan to offer only distance learning

- We plan to offer only faceto-face learning

Note. Figure developed by the author based on the results of the survey $(\mathrm{N}=43$; research period: May-June 2021)

Further, the analysis of the main challenges related to COVID-19 of educational institutions was conducted in the context of the transformation of the regions.

As it can be seen from Table 1, educational institutions admitted that the main challenge group during the pandemic was related to limitations with learners (higher number of applications, low digital skills, the inability of the learners to fully master the subject matter, learning only at a distance).

In addition, educational institutions admitted that due to the increase in demand for programmes, teachers are overloaded. Also, it is challenging for teachers to involve learners in the distance educational process, often it is due to the inability to use advanced techniques for distance learning or specifics of the subject.

Referring to technological challenges, there are limitations regarding the availability and functionality of computer equipment for learners, as well as educational institutions were forced to contribute to the development of e-platform.

To sum up, educational institutions also defined some administrative challenges like fragmented information and lack of methodological materials from state institutions regarding the organisation of the learning process. 
Further analysis was conducted in terms, of whether there are significant differences in results of the survey between those educational institutions that offered only face-toface learning processes and those who offered both face-to-face and distance learning processes or only distance learning processes before the pandemic.

\section{Table 1}

\section{Main Challenges of Educational Institutions During the Pandemic}

\begin{tabular}{|c|c|}
\hline Group of challenges & Challenge \\
\hline \multirow{3}{*}{$\begin{array}{l}\text { 1. Challenges related } \\
\text { to learners }\end{array}$} & Number of applications \\
\hline & $\begin{array}{l}\text { The inability of the learners to fully master the subject matter, learning } \\
\text { only at a distance }\end{array}$ \\
\hline & Low digital skills \\
\hline \multirow{3}{*}{$\begin{array}{l}\text { 2. Challenges related } \\
\text { to teachers }\end{array}$} & Teachers' overload \\
\hline & Teachers' skills to involve learners in the distance education process \\
\hline & Teachers' overload \\
\hline \multirow{2}{*}{$\begin{array}{l}\text { 3. Technological } \\
\text { challenges }\end{array}$} & Availability and functionality of the equipment for learners \\
\hline & Functionality of e-platform \\
\hline \multirow[t]{2}{*}{$\begin{array}{l}\text { 4. Administrative } \\
\text { challenges }\end{array}$} & $\begin{array}{l}\text { Fragmented information about the organisation of the distance educa- } \\
\text { tion process from state institutions }\end{array}$ \\
\hline & $\begin{array}{l}\text { Lack of recommendations / methodological materials from state insti- } \\
\text { tutions on organisation of distance education process }\end{array}$ \\
\hline
\end{tabular}

Note. Figure developed by the author based on the results of the survey $(\mathrm{N}=43$; research period: May-June 2021

As it can be seen from Figure 3, the main difference in rankings relates to technological challenges. Those education institutions that offered distance learning before the pandemic, found technological challenges insignificant.

\section{Figure 3}

Comparison of Rankings of Main Challenges of Educational Institutions During the Pandemic: Education Institutions That Offered Only Face-to-Face Learning vs Educational Institutions That Offered Both Face-to-Face and Distance Learning or Only Distance Learning Before the Pandemic

Offered face-to-face learning
1.Challenges related to learners
2.Technological challenges
3.Challenges related to teachers
4.Administrative challenges

Offered both face-to-face and distance
learning
1.Challenges related to learners
2.Challenges related to teachers
3.Administrative challenges
4.Technological challenges

Note. Figure developed by the author based on the results of the survey $(\mathrm{N}=43$; research period: May-June 2021) 
To determine whether there are significant differences in the assessments between educational institutions that offered only face-to-face learning before the pandemic and those that offered both face-to-face and distance learning or only distance learning before the pandemic, an F-test was performed to see if there was a significant variation between these samples. The calculations showed that in cases of "Technological challenges" and "Challenges related to teachers" the value of $\mathrm{F}$ was lower than the critical value of $\mathrm{F}$. This means that the null hypothesis of equal variations in both samples cannot be rejected at the significance level $\alpha=0.05$ and the variations in both samples are the same in these cases. However, regarding "Challenges related to learners" and "Administrative challenges" F-test showed that the variations are significant.

Then the relevant $t$-test was performed, i.e., the null hypothesis (Ho) was put forward that the averages of both samples (education institutions that offered only face-to-face learning before the pandemic and education institutions that offered both face-to-face and distance learning or only distance learning prior the pandemic) for each group of challenges are equal at a significance level $\alpha=0.05$ (see Table 2). The calculation showed that the statistical value of $t$ has been higher than the critical value of $t$ at the significance level $\alpha=0.05$ for such groups of the challenge as "Technological challenges" and "Challenges related to learners". This means that the null hypothesis has to be rejected and there are significant differences between the means of the two samples. Therefore, it must be concluded that there are significant differences in the assessment of the groups of challenges "Technological challenges" and "Challenges related to learners" between education institutions that offered only face-to-face learning before the pandemic and those educational institutions that offered both face-to-face and distance learning or only distance learning prior the pandemic.

The analysis proved that technological challenges were insignificant for those educational institutions that offered distance learning before. In addition, these education institutions found it challenging to deal with issues related to learners (especially, regarding the increasing number of applicants).

\section{Table 2}

Results of t-Test Two-Sample Assuming Equal and Unequal Variances (Group of Challenges) by the Form of the Learning Process

\begin{tabular}{|c|c|c|c|}
\hline Group of challenges & $\begin{array}{l}\text { t statistical } \\
\text { value }\end{array}$ & $\begin{array}{l}\text { t critical } \\
\text { value }\end{array}$ & Result \\
\hline Technological challenges & 4.04 & 2.01 & Ho rejected $\rightarrow$ there is statistical significance \\
\hline Challenges related to learners & 2.25 & 2.01 & Ho rejected $\rightarrow$ there is statistical significance \\
\hline Challenges related to teachers & 1.11 & 2.01 & $\begin{array}{l}\text { Ho cannot be rejected } \rightarrow \text { there is no statistical } \\
\text { significance }\end{array}$ \\
\hline Administrative challenges & 1.02 & 2.01 & $\begin{array}{l}\text { Ho cannot be rejected } \rightarrow \text { there is no sta- } \\
\text { tistical significance }\end{array}$ \\
\hline
\end{tabular}

Note. Figure developed by the author based on the results of the survey $(\mathrm{N}=43$; research period: May-June 2021) 
In other cases (groups of challenges "Challenges related to teachers" and "Ad-ministrative challenges") there are no differences in assessments between educational institutions that offered only face-to-face learning before the pandemic and those educational institutions that offered both face-to-face and distance learning or only distance learning prior the pandemic.

\section{Discussion}

It is widely agreed that in the context of the transformation of the regions, human capital with advanced digital skills is crucial (e.g., Abdurakhmanova et al., 2020). The survey showed that one of the main challenges for educational institutions during the pandemic was the low digital skills of learners. However, at the same time, distance or hybrid learning programmes can contribute to the improvement of digital skills that might lead to the development of the business sector as well.

Most of the surveyed educational institutions admitted that the number of applications increased during the pandemic. It may be explained by the fact that learners can participate in the distance learning process regardless of their place of residence. Distance learning may also cause savings regarding time and financial resources (e.g., travel expenses). Since most educational institutions are located in Riga, applicants from the regions may apply for the interested distance programmes without additional spending on travel. Thereby, it may be concluded that distance adult learning contributes to the development of human capital in the regions.

In addition, the results of the survey showed that educational institutions are intended to offer distance adult learning programmes in the future as they see opportunities related to the extended target audience (from the regions and abroad). To proceed with these plans, educational institutions should analyse which educational programmes have been organised in distance, hybrid, or face-to-face form as not all subjects could be fully transferred to the distance model. In this context, responsible state institutions (Ministry of Education and Science of Republic of Latvia, State Education Development Agency) should launch initiatives supporting transformation to distance model providing adult education institutions with training, seminars for good practice exchange, support for technological solutions, etc. In addition, responsible state institutions should provide educational institutions with step-by-step recommendations and methodological materials to support the development of distance adult programmes. These materials would be useful to all adult education institutions: for those educational institutions that had not offered distance learning programmes before the pandemic, the materials should focus on technological challenges. At the same time, for the rest of the educational institutions, the materials should focus on tackling the challenges related to learners (how to involve 
learners in the distance learning process; how to digitalise the content of the subject to distance learning form, etc.).

Taking into consideration the abovementioned, the answer to the research question (How COVID-19 can promote the transformation of the regions through adult education?) is formulated as follows: based on the survey on adult education institutions, COVID-19 related restrictions forced the educational institution to shift to distance form of education, including adult education. Since distance learning as itself does not limit the target audience by the place of residence, adult learners from the Latvian regions have been applying for interesting online programmes, thereby saving time and travel expenses and developing the competencies. Also, by studying at distance adult education programmes, adult learners improve their digital skills which are crucial for the digital transformation of the regions.

Future research directions related to the development of the distance adult education sector in Latvia will include the analysis of benefits of distance adult learning during the pandemic, as well as the development of future scenarios regarding the distance adult learning sector in Latvia.

\section{Conclusions}

The research showed that distance adult education may contribute to the digital transformation of the regions, since potential adult learners may choose interesting programmes regardless of the place of residence. Since most of the adult education institutions in Latvia are located in Riga, distance adult education programmes may provide potential adult learners from the regions with relevant knowledge, skills, and competencies contributing to the transformation of the regions.

Due to the pandemic, educational institutions in Latvia were forced to overcome different challenges to ensure the distance learning process. This transfer had also contributed to the improvement of digital skills which is one of the main barriers to digital society in Latvia. The transition to distance mode was more challenging to educational institutions without previous experience in the distance learning process due to technological limitations. However, educational institutions with previous experience in the distance learning process faced limitations regarding learners (their digital skills, involvement in the process, comprehension).

At the same time, not all adult learning programmes may be transferred to the distance model, thereby educational institutions should assess which programmes should be developed in face-to-face, distance, or hybrid models.

It is concluded that in Latvia, the distance adult education sector will develop in the future since most of the educational institutions had admitted continuing offering distance programmes also in the post-pandemic period. Thereby, step-by-step recommendations 
and methodological materials will be valuable for the adult education institutions in this context. In addition, responsible authorities (Ministry of Education and Science of Republic of Latvia, State Education Development Agency) should organise workshops to share good practices in ensuring distance adult learning process as well as training to teachers and employees of educational institutions aiming to overcome different challenges.

\section{Acknowledgement}

This work was supported by the post-doctoral research aid programme's project „Development of online adult learning in response to COVID-19 for digitalization and economic growth of the regions in Latvia" (No.1.1.1.2/VIAA/4/20/616).

\section{References}

Abdurakhmanova, G., Shayusupova, N., Irmatova, A., \& Rustamov, D. (2020). The role of the digital economy in the development of the human capital market. International Journal of Psychological Rehabilitation, 24(7), 8043-8051.

Barnard-Brak, L., Lan, W. Y., \& Paton, V. O. (2010). Profiles in self-regulated learning in the online learning environment. International Review of Research in Open and Distance Learning, 11(1), 61-80.

Berry, G. R., \& Hughes, H. (2020). Integrating work-life balance with 24/7 information and communication technologies: The experience of adult students with online learning. American Journal of Distance Education, 4(2), 91-105.

Blieck, Y., Kauwenberghs, K., Zhu, C., Struyven, K., Pynoo, B., \& DePryck, K. (2019a). Investigating the relationship between success factors and student participation in online and blended learning in adult education. Journal of Computer Assisted Learning, 35(4), 476-490.

Blieck, Y., Ooghe, I., Zhu, C., Depryck, K., Struyven, K., Pynoo, B., \& Van Laer, H. (2019b). Consensus among stakeholders about success factors and indicators for quality of online and blended learning in adult education: a Delphi study. Studies in Continuing Education, 41(1), 36-60.

Cocquyt, C., Diep A. N., Zhu, C., de Greef, M., \& Vanwing, T. (2017). Examining social inclusion and social capital among adult learners in blended and online learning environments. European Journal for Research on the Education and Learning of Adults, 4(2), 139-152.

Cross-Sectoral Coordination Centre of Latvia. (2010). Sustainable development strategy of Latvia until 2030. https://www.pkc.gov.lv/sites/default/files/inline-files/LIAS 2030 en 1.pdf

de Greef, M., Verté, D., \& Segers, M. (2015). Differential outcomes of adult education on adult learners' increase in social inclusion. Studies in Continuing Education, 37(1), 62-78. 
Diep, N. A., Cocquyt, C., Zhu, Ch., Vanwing, T., \& de Greef, M. (2017). Effects of core selfevaluation and online interaction quality on adults' learning performance and bonding and bridging social capital. The Internet and Higher Education, 34, 41-55. https://doi.org/10.1016/j. iheduc.2017.05.002

European Commission (2020a). Digital economy and society index (DESI) 2020: Latvia. https:// ec.europa.eu/newsroom/dae/document.cfm?doc id=66919

European Commission. (2020b). Communication from the Commission to the European Parliament, the Council, the European Economic and Social Committee of the Regions: Digital education action plan 2021-2027 resetting education and training for the digital age (COM/2020/624 final). https://eur-lex.europa.eu/legal-content/EN/TXT/?uri=CELEX:52020DC0624

European Commission. (2021). Digital technologies - actions in response to coronavirus pandemic. https://ec.europa.eu/digital-single-market/en/content/digital-technologies-actions-responsecoronavirus-pandemic

Jekabsone, I., \& Gudele, I. (2021). Challenges of the adult learning sector in the context of COVID-19 in Latvia. Economic Science for Rural Development (accepted).

Latvijas Vestnesis (1998). Education law of the republic of Latvia. https://likumi.lv/ta/en/en/ id/50759-education-law

Lee, K., Choi, H., \& Cho, Y. H. (2019). Becoming a competent self: a developmental process of adult distance learning. The Internet and Higher Education, 41, 25-33. https://doi.org/10.1016/j. iheduc.2018.12.001

Ministry of Education and Science of the Republic of Latvia. (2021). State education information system - register of educational institutions. https://viis.lv/Pages/Institutions/Search.aspx

Vanslambrouck, S., Zhu, Ch., Pynoo, B., Lombaerts, K., Tondeur, J., \& Scherer, R. (2019). A latent profile analysis of adult students' online self-regulation in blended learning environments. Computers in Human Behavior, 99, 126-136. https://doi.org/10.1016/j.chb.2019.05.021

\title{
COVID-19 ir suaugusiujų švietimas - Latvijos regionų pasikeitimo kelias
}

\author{
Inga Jekabsone
}

Magnetic Professional, Ltd, Gustava Žiemgala alëja 78-1, LV-1039 Ryga, Latvija, jekabsone47@gmail.com

\section{Santrauka}

Šio tyrimo tikslas - išanalizuoti COVID-19 pasekmes Latvijos suaugusiųjų švietimo sektoriui regioninio pertvarkymo kontekste. Taikyti šie tyrimo metodai: mokslinès literatūros analizè, Latvijos mokymo įstaigų suaugusiųjų apklausa $(\mathrm{N}=60)$. 
Pagrindinès tyrimo išvados rodo, kad pandemijos laikotarpis suaugusiųjų mokytojams ir besimokantiems suaugusiesiems visoje Latvijoje sukèle ịvairių iššūkių, ypač susijusių su skaitmeniniais ignūdžiais, technologinèmis problemomis ir dalyko turinio transformavimu i nuotolinị mokymąsi.

Apklausos rezultatai leidžia daryti išvadą, kad COVID-19 situacija prisideda prie regionų pasikeitimo ugdant žmogiškojo kapitalo žinias, igūdžius ir kompetencijas, nes dèl nuotolinio mokymosi proceso suaugusieji gali pretenduoti ị įdomias ugdymo programas, nepaisydami gyvenamosios vietos.

Praktinė tyrimo reikšmė yra ta, kad pateikiamos rekomendacijos suaugusiųjų švietimo institucijoms ir atitinkamoms valdžios institucijoms nuotoliniam arba hibridiniam suaugusiųjų mokymosi procesui parengti. Straipsnis yra originalus, nes jame analizuojamos COVID-19 pasekmès suaugusiųjų švietimo sektoriui Latvijoje. Straipsnio vertè yra ta, kad apžvelgiama nemažai suaugusiųjų švietimo ịstaigų Latvijoje, ịskaitant ir tas, kurios yra regionuose.

Esminiai žodžiai: COVID-19, suaugusiųų švietimas, skaitmeninimas, regionai, Latvija, pasikeitimas.

Gauta 20210812 / Received 12082021

Priimta 20211227 / Accepted 27122021 